\title{
INTRODUCTION TO THE AJIL UNBOUND SYMPOSIUM ON ELEPHANT LAW
}

\section{Jacqueline Peel*}

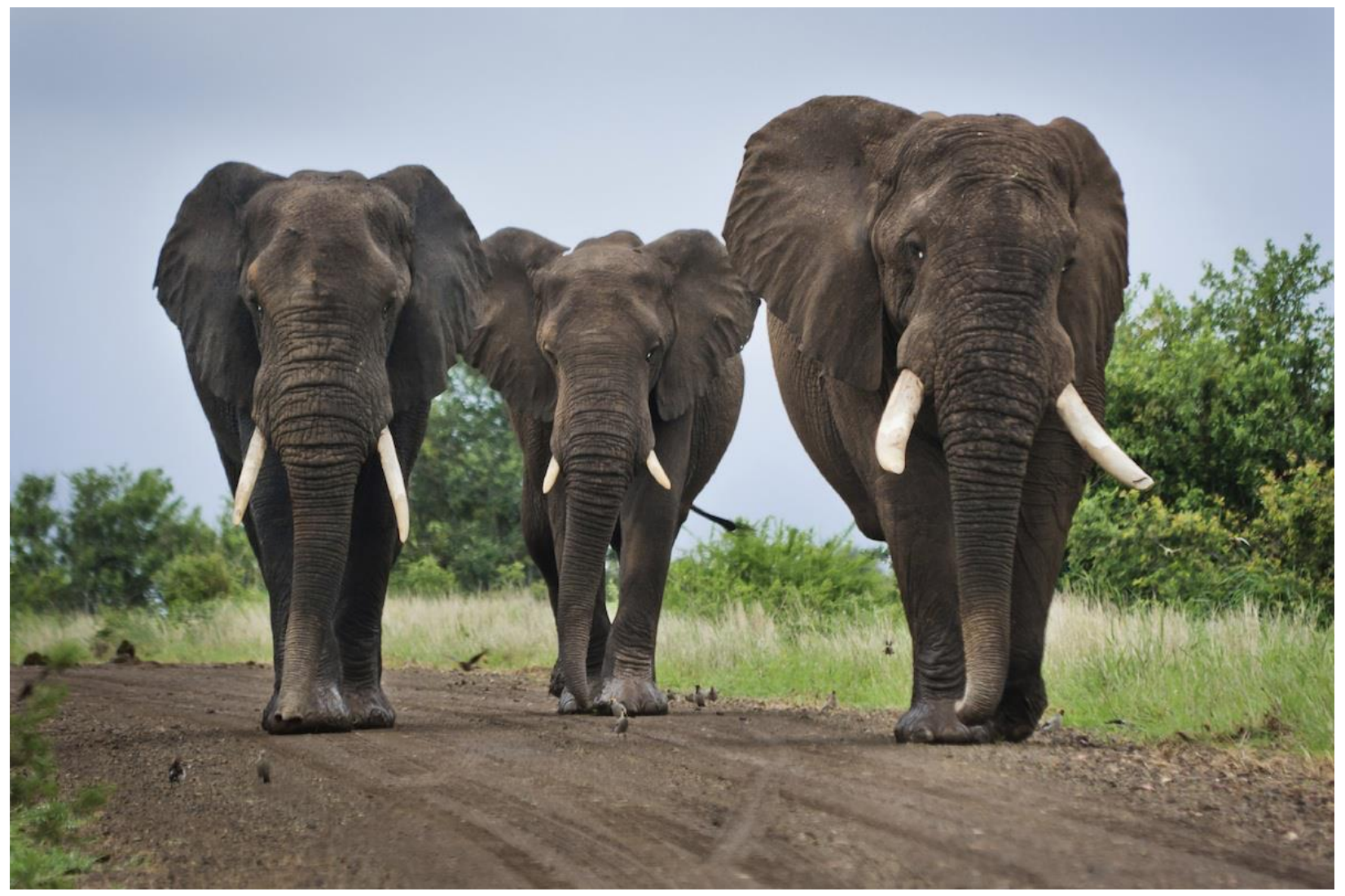

In international environmental law, the elephant is an icon. Like other "charismatic megafauna" such as whales and pandas, the plight of the elephant has captured the imagination of the general public and generated a raft of international regulations. In efforts to protect the elephant, we can track many of the elements of international law that have been characteristic of the environmental field as a whole: historical beginnings in concerns to prevent the over-exploitation of a harvested species; the rise of notions of biodiversity that attribute intrinsic worth to nonhuman beings; the use of trade measures as part of international environmental agreements to aid enforcement efforts; the growing complexity of environmental problems with

* Professor of Law at Melbourne Law School, Australia, and co-chair of the ASIL International Environmental Law Interest Group.

Originally published online 21 Nov. 2014. 
globalization; and the increasing inter-linkage of international environmental law with other fields of international law.

The three pieces in this Symposium speak particularly to the elephant as an exemplar of the increasing complexity and inter-linkage of international environmental law. Each piece is critical of the existing international environmental regime applicable to elephant protection, highlighting the limits of treaties such as the Convention on International Trade in Endangered Species of Flora and Fauna ${ }^{1}$ to deal with the range of new threats that elephants currently face. Principal among these are poaching of elephants and illegal trafficking in their ivory, with much of this activity run by organized crime groups to fuel armed conflict. Indeed, these threats have reached such a level recently as to pose a real risk of extinction of the species. Scientists have found that a surge in illegal killing for the ivory trade is leading to a global decline ${ }^{2}$ in the population of African elephants.

For the first piece in the Symposium, André Nollkaemper explains the variety of ways that international law has "framed" elephant protection over time, leading to different forms of regulation. The historical "hunting frame," which protected elephants in order for them to be killed for their ivory and as trophies, has been superseded by several modern frames that variously construct elephant protection as a matter of biodiversity conservation, crime control, peace and security, or development. Nollkaemper emphasizes the need for greater alignment between these frames and the work of associated institutions to improve the prospects for elephant protection. He proposes action by the UN General Assembly as a basis for creating "a common political platform where frames can communicate, tensions can be articulated, and synergies may be found."

Anne Peters' contribution to the Symposium expands on the use of the peace and security framing in elephant protection efforts. She discusses the novel practice of the Security Council recognizing wildlife poaching and trafficking as a threat to peace and security. Peters notes that the anthropocentric motivations for the relevant Security Council resolutions issued in January $2014^{3}$ are a double-edged sword. On the one hand, the links between ivory trafficking and conflicts in parts of Africa are undoubtedly what prompted the Security Council's action. On the other hand, such an anthropocentric approach is inimical to the developing norms of global animal law to which the Security Council resolutions might be seen to contribute. Peters concludes that the new Security Council resolutions are a welcome extension of its previous practice to develop an "enlarged" and "positive" concept of peace; one that takes into account not only human security but also "the integrity of nature, the survival of species, and the well-being of animals."

The final piece in the Symposium, authored by Rachelle Adam, takes up the case for a new treaty to halt the ivory trade. Acknowledging the complex nature of threats to the elephant and the multitude of international forums implicated by protection efforts, Adam suggests that the most appropriate institution to house a new treaty is most likely one in the field of transnational organized crime or human rights, rather than the environmental domain that has traditionally been the source of international laws on the elephant. Like Peters, however, Adam sees a need for animal welfare issues to become a greater part of the international response to elephant protection, urging that "the elephant crisis is a moral issue of humans' cruelty to animals." Nollkaemper has also noted ${ }^{4}$ the limited impact to date of "an animal rights frame" compared with anthropocentric peace and security frames; as we have seen in other environmental contexts, including cli-

1 See CONVEntion on International Trade in Endangered SPECiEs OF Wild Fauna ANd Flora [CITES].

${ }^{2}$ George Wittemyer et al., Illegal Killing for Ivory Drives Global Decline in African Elephants, 111 Proc. NAT'L ACAD. SCI. U.S.A 13117 (2014).

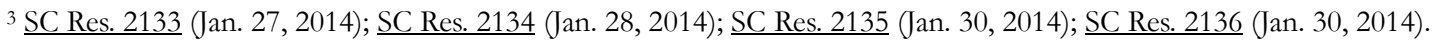

${ }^{4}$ André Nollkaemper, Framing Elephant Extinction, 3 ESIL REFLECTION 2 (July 15, 2014). 
mate change, 5 " $[\mathrm{w}]$ hoever succeeds in attaching the security label to the protection of any interest, gains significant momentum in triggering effective action."

The pieces in this Symposium draw from the work and expertise of the ASIL-ESIL Elephant Law Forum, a collaborative group bringing together members of the ASIL International Environmental Law Interest Group and its ESIL counterpart, with an interest in elephant law. Further information on the ASIL-ESIL Elephant Law Forum and its activities can be found on the webpage of the ASIL International Environmental Law Interest Group. ${ }^{6}$

5 Security Council Holds Open Debate on Climate Change: Agrees on a Presidential Statement, UN NON-GOvernMENTAL LiAISON SERviCE (2011).

6 See International Environmental Law, ASIL. 